\title{
Methodical Motivation of the Using EVA (Economic Value Added) as Instrument of Cost-Performance Management in Organizations
}

\author{
Pavel V. Limarev \\ Nosov Magnitogorsk State Technical University \\ Yulia A. Limareva \\ Nosov Magnitogorsk State Technical University \\ Ekaterina G. Zinovyeva
}

Nosov Magnitogorsk State Technical University

Elena G. Usmanova

Tyumen State Oil and Gas University (Noviy Urengoy Branch); Email: sci.publ@gmail.com

Doi:10.5901/mjss.2015.v6n5s2p489

\section{Abstract}

Transition to firm economic development is connected with decision of microeconomics problems - increasing economical efficiency of organizations. This problem predestines the behavior of the economic subject on the market of goods and resource, dictates the strategy of the development by potential to business activity. The market economy and fundamental changes in the modern social and economic development of Russia, transition to sustainable and long-term economic growth are associated with solving the key microeconomic objective to be the increase in economic efficiency of the enterprises and organisations. Launching the efficiency controlling action-oriented tools to allow within the selected economic strategy to develop an economic entity's line of behavior in the market and create the optimal system of the current activity arrangement is required. The regional printed media is no exception in this respect. The purpose of persisting studies was shown development instrument cost-performance management to activity of the economic as institutional subject of the of market economies, and their prima-thread on example of organization - a publishers regional printed mass-media. The Authors are given methodical motivation of the using economical value added as instrument of cost-performance management in organization-publisher.

Keywords: cost-performance, economical value added, organizations-publishers regional printed mass-media, instruments of costperformance management.

\section{Introduction}

Advancement of organisations - publishers in Russia's regions is significantly hindered by insufficient attention paid by their CEOs to economic efficiency management i.e. organisation structures efficiency, technological processes and sales management.

Up to date, no comprehensive tool kit of economic entity efficiency management of a regional printed media publisher, in particular, have been created. The timeliness of the present study is predetermined by this fact.

The problem of an enterprise economic efficiency management is typical not only for Russia. David Ricardo (2001), a classic of political economy, was the first to study the issue of economic efficiency. Such foreign researchers as A. Maslow (1954); R. Cyert and J. March (1963); J. Donnelly, J. Gibson and J. Ivanchevich [16] paid and currently pay much attention to this issue. In Russia, the concept of economic efficiency was investigated S.A. Bartenev, A.S. Bulatov, E.I. Krylov, V.V. Novozhilov, T.S. Khachaturov, L.E. Kunelskiy, N.A. Petukhova, B.A. Raizberg and other scientists.

Organisations - publishers of the printed media are no exception in the issue of cost-effective management. Economic problems of the Russian printing organisations were discussed in the papers of G.M. Avramenko, V.A. Biryukova, V.A. Bogomolova, M.V. Vasilovskaya, V.V. Voroshilov, A.P. Griţsuk, P.S. Gurevich, S.M. Gurevich, S.V. Datsko, O.V. Dmitrieva, V.K. Kondrashova, A.E. Margolin, E.M. Margolin, E.M. Merzlikina, A.N. Nazaykin, E.V. 
Nikolskaya, A.P. Repyov, G.N. Stepanova, K.K. Chaplygin, R.A. Chvanova, E.K. Frolova and other scholars. Abroad, the efficiency of the printed media was studied by such researchers as S. Hennaford (2007); K. Fink (1996); T. Mendel (2003) and others.

The problems impeding the use of the integrated mechanism of the business entities - the publishers of regional printed media efficiency management are: the lack of the unified methodological approach to setting up the system of economic entity efficiency management, the shortage of highly qualified developers, underfunding and lack of expertise in the field of management theory and underevaluation of practical effects from the implementation of economic efficiency management tools. The issues of theoretical and methodological foundations of the efficiency management have been studied insufficiently, for example, the necessity to introduce integrated management tools for small-scale businesses, working as Russia's economic base and foreign management experience application have been poorly grounded. We do not have a universal mechanism to establish the integrated system of management for small-scale business organizations. The mechanism which enhances their competitiveness in the market of the regional printed media.

In the course of the preliminary research conducted to identify the business entity economic efficiency management tools using the example of the organization - the publisher of the regional printed media, it was found out that the generalized indicator of economic efficiency is an added value.

\section{Model and Data}

Business entity performance management is a business strategy combining interrelated managerial activities, processes and tools.

Economic efficiency management of the business organisation includes many processes, starting with current planning and budgeting to forecasting and simulating.

When considering the organisation as a system, and relying upon the institutional approach it must be said that a present-day organization is influenced by both internal and external environment. Therefore, performance management should be set up in such a manner as to impart the economic entity flexibility and efficient adaptability to the external effects.

We will give consideration to the distinctive features of the management activities in comparison with any other business activities.

1. Forecasting and planning of the business entity activities. Using the statistical models the interrelations between the various factors of production and the eventual outcome of the organization were found: regression analysis, multiple factor analysis, extrapolation of time series. For analyzing and forecasting of the market conditions, they use the methods of induction and deduction, experiment and observation. Ultimately, to produce a high-quality economic forecast they use economic and mathematical models of market conditions development and those of the economic entity in it. Forecasting is inextricably linked with planning. According to the forecast produced, there takes place business entity planning taking into account the available resources and their optimal use.

2. Establishing an organization involves setting up its organization structure, fixing staffing structure with separation of rights and obligations among the personnel. The correct distribution of power allows one to use resources more economically and allocate them in accordance with the needs of the organization.

3. Management of the organisation involves drawing up orders and instructions and making sure that the staff executors receive them timely and understand them properly.

4. Coordination of the organisation's work involves coordination of actions among the various departments to achieve the result through joint efforts. This function allows one to find a compromise between the needs and the resources of units and to take the best management decision.

5. Control. The control function is day-to-day monitoring and checking the activities of the certain areas of work and the organisation as a whole. Control is performed to see the deviations of actual indicators of the organisation from their planned ones.

In papers (M.Abrjutina, 2002, C.Datsko, 2008, E. Merzlikina 2012) the use of economic added value when drawing up the organisation's budget, evaluation of effectiveness of its activities and management bonuses planning was discussed.

The value-added method is a method to account income included in the System of National Accounts (SNA). To evaluate the organisation's cost-effectiveness from the view point of the state's economic interests, the value added indicator is calculated by establishing the economic turnover balance (ETB).

Added value for publishing activity in the system of national accounts can be calculated on the basis of the 
statistical data collected. The added value produced by the organisations - the publishers of the printed media can be calculated by accounting documents using the technique proposed by M.S. Abryutina in her paper "Rapid Analysis of Financial Statements" (Abrjutina. 2002). Comparison of the indicators as a whole for regarding the kind of activity and for particular enterprises will show in which way the economic efficiency of the regional publishing houses differs from the economic efficiency of the activity in general, and the factors influencing the added value receipts will become an economic efficiency management tool.

The added value of a product is the difference between the total receipts from its sale and its intermediate production costs:

$$
A V=R-I_{p}
$$

where $A V$ is value added;

$R$-is receipts;

Ip is intermediate production costs.

Receipts and intermediate costs (which include material costs (commodities and tangible services), including raw materials, purchased components and semi-finished products, work and production services provided by other organizations; fuel; electric power; thermal energy; payment for non-material services; travel expenses covering return tickets, accommodation, rents, other elements of intermediate consumption) are available from the balance sheet of the enterprise.

The specific character of the organisation - the publisher of the regional printed media - is that both of these parameters for the forthcoming accounting period are quite accurately predicted, and the receipts forecast have an upperbound constraint: the edition can not place more advertising than it is permitted by the current law and the sales of the circulation (if it is a paid sale) is always calculated for the coming accounting period in advance as a result of the subscription campaign, coupled with the agreements with retailers (JSC "Rospechat", etc.) (C.Datsko, 2008).

At the end of the last century, many organizations started using added value management systems - EVA (economic value added), CVA (cash value added), SVA (shareholder value added), MVA (market value added) and so on. These systems are registered trademarks and they are currently being used by most companies.

Table 1 shows the system of value added indicators used and their characteristics.

Table 1. System value added indicators

\begin{tabular}{|c|c|c|c|}
\hline Indicator & Characteristic & Calculation Method & Symbol \\
\hline CVA - Cash Value Added & $\begin{array}{l}\text { It shows the ability of an enterprise to } \\
\text { cover operating expenses and the } \\
\text { cost of capital }\end{array}$ & $\begin{array}{l}C V A=A O C F-W A C C \times T A \\
C V A=O C F-O C F D\end{array}$ & $\begin{array}{l}\text { AOCF - adjusted operating cash flow; } \\
\text { WACC - weighted average price of capital; } \\
\text { TA - total adjusted assets; } \\
\text { OCF - operating cash flow; } \\
\text { OCFD - cash flow from operating activity } \\
\text { claims }\end{array}$ \\
\hline $\begin{array}{l}\text { SVA - Shareholder Value } \\
\text { Added }\end{array}$ & $\begin{array}{l}\text { It is used to obtain in-formation on the } \\
\text { return on investments made. }\end{array}$ & $S V A=S H_{P}-S H_{5}$ & $\begin{array}{l}\mathrm{SH}_{P}-\text { estimated cost of the equity capital } \\
\mathrm{SH}_{5} \text { - balance-sheet value of the equity } \\
\text { capital }\end{array}$ \\
\hline MVA - Market Value Added & $\begin{array}{l}\text { It is used to evaluate the efficiency of } \\
\text { the company's equity capital use }\end{array}$ & $M V A=P C-I C$ & $\begin{array}{l}P C \text { - market price of the capital } \\
\text { IC - invested in the company capital }\end{array}$ \\
\hline EVA - Economic Value Added & $\begin{array}{l}\text { It is used to evaluate company's } \\
\text { efficiency from the owners' } \\
\text { perspective }\end{array}$ & $\begin{array}{l}E V A=(P-T)-I C \times W A C C= \\
N P-I C \times W A C C=(N P / I C- \\
W A C C) \times I C\end{array}$ & $\begin{array}{l}P \text { - operating profits; } \\
T \text { - taxes and other mandatory payments; } \\
N P \text { - net profit }\end{array}$ \\
\hline
\end{tabular}

\section{Empirical Results}

Economic value added (EVA) is the most appropriate value for our research objectives as other methods will give less accurate results: cash flows, change in the market value of the company, change in proprietary capital value will not allow to evaluate accurately the value added collected by the enterprise - the publisher.

The EVA indicator among other things allows us to estimate the ratio of equity and loan capital:

$E V A=(P-T)-W A C C \times C E$

where $P$ is a profit;

$T$ is amount of taxes;

WACC is a weighted average price of capital;

$C E$ is invested in the company capital (a liability side of the balance-sheet).

A weighted average price of capital (WACC) can be calculated as follows: 
$W A C C=P_{3 K} \times d_{3 K}+P_{C K} \times d_{C K}$

where $P_{3 \kappa}$ is the amount of loan capital;

$d_{3 k}$ is a share of the loan capital in the structure of the enterprise;

$P_{C K}$ is the amount of the proprietary capital;

$d_{C K}$ is the share of the proprietary capital in the structure of the enterprise.

The balance-sheet of the organisation - the publisher of the printed media is the source of data to calculate the value added. Table 2 shows the options of the economic added value management for the organization - the publisher of the regional printed media.

Table 2. Economic added value management

\begin{tabular}{|l|l|l|}
\hline Object of Management & Objective of the Action & Outcome of the Action \\
\hline EVA & $\begin{array}{l}\text { Increase in profits under the } \\
\text { previous amount of capital }\end{array}$ & $\begin{array}{l}\text { 1. Finding new advertising and information fractions of market; } \\
\text { 2. Expanding readership; } \\
\text { 3. Optimisation of taxes and other mandatory payments under the } \\
\text { legislation of the Russian Federation }\end{array}$ \\
\cline { 2 - 3 } & $\begin{array}{l}\text { Reduction of the amount of } \\
\text { capital at the current profits }\end{array}$ & $\begin{array}{l}\text { 1. Reduction of the edition production costs; } \\
\text { 2. Replacing costly production process phases for less costly ones; } \\
\text { 3. Optimising payroll budget distribution }\end{array}$ \\
\hline
\end{tabular}

EVA indicator shows the change in the market value of the organisation as a result of its business activities, i.e. the market value of the company may differ from the balance-sheet value of net assets at the amount of added value in the future time periods, both on the plus side and the minus ones. This indicator means a high degree of responsibility of the company's officers for the its generation and, consequently, it is the basis of the top management's motivation dependence on the change in economic value added.

One of the criteria to evaluate the economic efficiency of the business entity is a change in EVA indicator during the accounting period. Since this indicator is not taken into consideration in the organisation's accounting system, this figure can be derived through forming the balance of economic turnover, which is generated with financial statement indicators. Since EVA indicator to a larger extent shows a company's contribution in the country's GDP raising than the economic condition of the enterprise, to evaluate adequately its condition, other indicators are to be taken into consideration. These indicators can appear to be:

- return on the capital invested;

- $\quad$ an integral indicator to factor the ratio of revenues and expenses and the amount of bills payable;

- economic profit.

Return on the capital invested is a measure of the company's business activity. The integral indicator (E.Merzlikina, 2012) is a static measure of the company's management financial efficiency. It is calculated in the following way:

$$
K_{И}=\frac{\not}{P} \times\left(1-\frac{K 3_{K}}{K 3_{H}}\right),
$$

where $K u$ is an integral coefficient of revenues and expenses accounting;

$\boldsymbol{Z}$ is a revenue during the accounting period (a month);

$P$ is expenses during the accounting period;

$K 3_{K}$ is bills payable at the end of the period;

$K 3_{H}$ is bills payable at the beginning of the period.

Economic profit is a criterion of the enterprise resources efficiency. Unlike the value added indicator, the source for these indicators calculation is not a balance sheet but a budget of the organization. While evaluating efficiency, we compare the indicators available with the reference ones, planned budget figures make a basis for benchmarking and performance and targeting actual indicators. The efficiency of business (company officers' performance) can be assessed using certain of quantitative indicators depending on the company's core activities and overriding priorities of the company's expansion. The following objectives, except profit gaining, can be proposed for the organization - the publisher of the printed media:

Establishing public attitudes including the creation of a positive or a negative image of the public figures;

Establishing company's own positive image in the social environment;

Improving social, cultural and environmental conditions in the sphere of mass media influence.

The labour activity outcomes can be evaluated by its earning capacity under the current market conditions. 
Productivity and performance in the course of the manufacturing process are taken into consideration for accounting the cost of production.

Labour return rise is an important indicator of the company's economic efficiency: company's employees' income rise and labour return increase are criteria to assess the outcomes of labour remuneration management for the business entity. The coefficient of labour profitability is found as follows:

$$
K_{д T}=\frac{O \Pi}{\sum \Phi O T_{C}} \times 100 \% \text {, }
$$

where $\quad K_{\text {дт }}$ is a labour profitability coefficient;

OП is a pre-tax profit;

$\Phi O T_{C}$ is a pay-roll fund included in the cost of a product and calculated for the accounting period.

Employees' income rise influences the increase in cost of labour power and price of labour. Unjustifiably low wages in the domestic economy (the share of wages in the cost of goods manufactured is two times lower than that in the economically advanced countries) prove that there exist reserves to increase the price of labor, but it must be governed by the surpassing labour profitability rise.

There exists a functional relationship between wages and revenues generated from the labour activity (including the business one). There is also a feedback, since both wages and incomes depend on the labour outcomes.

\section{Results}

Using the management tools discussed above to control economic efficiency of the organisation - the publisher of the printed media is subject to evaluation. Economic efficiency of the activity is to be assessed by the change in the certain parameters, to be subject to the controlling actions. The controlling actions are aimed at, firstly, primary, production and business processes which result in the changes in the quantitative and qualitative indicators of the organisation. We believe that to measure these changes we need the following information: data on the product, production costs (material, organizational, etc.) and income derived after selling the product, besides, it is necessary to specify the period subject to the investigation.

The efficiency of the organisation can be evaluated by comparing the outcomes of the controlling action on the production or business process with the reference indicator of this process. The benchmarks used for comparison with the actual indicators are those, which were targeted in the plan or the budget at the appropriate time.

Financial planning of the organisation - the publisher of the printed media is based on the principles of budgeting. They lay out expenditures for each department, arrange a separate management accounting of costs (fixed, variable and mixed costs are allocated) and production costs are calculated using methods which clearly show the cost structure and the amount of fixed and variable costs. However, budgeting has several disadvantages because of the linear-functional management system, typical to the organisations - the publishers of regional printed media. It is difficult to use control tools, there is no responsibility centers, a stock of orders is not controlled (what it involves is long-term advertising agreements included in the budget), in addition, in most cases, managers responsible for budgeting lack experience and the required competence.

Measurement and evaluation of costs and revenues involves the choice of the optimal performance indicators. To assess the economic entity's performance, we use three groups of indicators to be subject to the controlling action:

A group of indicators of the organisation's financial condition;

A group of indicators of the human resources management system;

A group of indicators of the organisational structure performance.

The impact on any of the indicators results in the change in the indicators, using which one can make a conclusion about the effectiveness of the controlling action. The indicators can also be divided into three groups according to the types of economic efficiency: allocative efficiency, technical efficiency and business efficiency. Figure 1 shows the distribution of indicators to have been subject to the controlling action and parameters-indicators. Specialized software calculates all income and expense items, besides, it allows to calculate certain qualitative parameters and the corresponding change in quantitative parameters-indicators.

\section{Conclusions}

Thus, in the course of the research, the authors

found out the vectors of the controlling actions used for economic efficiency management of the organisation - 
the publisher of the regional printed media. The controlling actions are based on the analysis of interaction of all the company's elements as well as the analysis of the external and internal factors.

proposed to use the following economic efficiency management tools for the enterprise - the publisher of the regional printed media: a financial budgeting, business activity management, personnel management, cash flow management, economic profit management.

- found out that when using the economic efficiency management tools, it is necessary to rely upon the methods of comparative functional-structural analysis, system analysis of economic phenomena and processes, as well as the methods of economic and mathematical simulation.

- proposed to use budgeting as the optimal basis for the economic efficiency analysis of the organization - the publisher of the regional printed media.

- found that the proposed economic efficiency management tools, will allow to carry out regular monitoring of the actual performance indicators compliance with the criteria of the basic and functional business strategies, to enhance the managers' interest in the company's effective work; tackle problems of organisation's business activities evaluation in the conditions of market economy with larger objectivity and reliability.

\section{References}

Abrjutina, M. Financial analysis of commercial activity. - Moscow: Finpress, 2002.-176 p.

Beljanchev, V. Competition management of cost-performance managing subject at economical crisis. PhD economy dissertation. Moscow: 2011. -175 c.

Conrad C. Fink. Strategic Newspaper Management. - NY: Allyn \& Bacon, 1996. - 79 p.

Cyert, R., March, J. A Behavioral Theory of the Firm. - New Jersey, Prentice-Hall Inc, 1963. - 254 p.

Datsko, C. Technical efficiency of firm by publishers: monographic. - Moscow: MGUP named by Ivan Fedorov, 2008. - $128 \mathrm{p}$.

David Ricardo. On the Principles of the Political Economy and Taxation. - Ontario: Batoche Books, 2001. - 333 p.

From journalists to journalists. - British Council, 2007.

Hannaford Stephen G. Market Domination! Westport/CT, Praeger Publishers, 2007. - 184 p.

James, H. Donnelly, Jr., James, L. Gibson and John M. Ivanchevich. Fundamentals of Management. - Dallas: Business Publications, 1978.

Limarev P., Limareva, Y. Evaluating the effectiveness of a small business - the publisher of regional print media // Management in Russia and abroad. - 2010. - № 6. - C. 67-72.

Limarev, P. Management instruments of economical efficiency by regional print-media. PhD economy dissertation. - Moscow: MGUP named by Ivan Fedorov, 2012. - $145 \mathrm{c}$.

Maslow, Abraham H. Motivation and Personality. - NY: Harper and Row, 1954. - 91 p.

Mendel T. Freedom of information: A Comparative Legal Survey. UNESCO, 2003.

Merzlikina, E. Estimation of efficiency organization activity: monografic. - Moscow: MGUP named by Ivan Fedorov, 2012. - $93 \mathrm{p}$.

Vasilovskaya, M. Estimation of efficiency state management by economy of publishers. PhD economy dissertation. - Moscow: MGUP named by Ivan Fedorov, 2005. - 221c.

Volchek, V. Efficiency market' processes and evolution of institutes // Herald of high schools. Northern-Caucasian region. Society's sciensis. - 2002. - №4. - P. 43-50. 